\title{
The Importance of Stable Income Sources in Retirement: An Exploratory Study
}

\author{
Jim Sundali \\ University of Nevada, Reno \\ James W. Westerman \\ Appalachian State University \\ Yvonne Stedham \\ University of Nevada, Reno
}

\begin{abstract}
Spiraling compensation costs over the past two decades has led many firms to change their compensation strategies. There has been a shift in employee pension benefits as a form of compensation, as firms are rapidly moving from defined benefit plans towards defined contribution plans. In this study, we examine data and prior empirical analyses from the Health and Retirement Study to explore how this shift may affect retirees and employees. Based on an exploratory data analysis, we introduce a theoretical framework representing the relationship between retiree satisfaction and pension plans, and discuss its potential impact on organizations and their employees.
\end{abstract}

\section{Introduction}

With employee benefit costs rising at rates three to four times faster than inflation in the United States (Kalamas, Kuo, \& Ungerman, 2006), many firms are changing their benefit offerings in efforts to contain the costs, without much forethought as to the potential employee-level performance and attitudinal consequences. One particular area of employee compensation that has witnessed profound change is that of retirement pensions, as firms have shifted from the defined long-term liability of defined benefit (DB) pension plans towards the more flexible short-term costs of defined contribution (DC) pension plans. Whereas in $1983,70 \%$ of individuals between the ages of 56 and 64 had a DB plan, in 2001 this percentage had precipitously declined to $47 \%$ (Weller \& Wolf, 2005). Similarly, the US Department of Labor Statistics notes that the percentage of employees with defined benefits plans decreased from approximately $80 \%$ in 1985 to $21 \%$ in 2006 (US Department of Labor, 2004; 2006).

From a business management perspective, retirement funding takes on a critical role. Employers offer retirement plans as a voluntary (as opposed to mandatory) benefit. Despite the growing importance of employee benefits as both a significant expense and a valuable tool for firms to elevate themselves from their competition, researchers have been slow to respond to the need for empirical research on the impact of this wholesale shift toward DC retirement plans on employees and retirees (Williams, Malos, \& Palmer, 2002). Further, as the baby boom generation ages and approaches retirement, many developed nations (such as the United States, Germany, and Japan) are facing a 
profound economic and social challenge. Traditional funding of retirement in the form of social security systems and defined benefit pension plans are seen as unsustainable during today's economic conditions (The Board of Trustees, Federal Old-Age and Survivors Insurance and Federal Disability Insurance Trust Funds, 2008; Schieber \& Shoven, 1999). Subsequently, the debate among policymakers, scholars, and practitioners about the effectiveness and feasibility of various retirement funding schemes has become widespread. This study will offer a review of the literature, conceptual ideas, and theory building in regards to the relevance of DB and DC retirement plans to employees, managers, and their organizations.

\section{DB versus DC Retirement Plans: A Definition and Initial Conceptual Thoughts}

A DB plan is a retirement pension in which a retired employee receives a specific income based on salary history and years of service, and in which the employer bears the investment risk. Funding of the DB plan is typically borne by the employer, with the employee sometimes also making contributions. Upon retirement the employer is contractually obligated to deliver a pension income to the employee on a regular basis. In contrast, a DC pension plan is a benefit in which the employer contributes a specified amount toward an employee's retirement. Typically, the employer will contribute a fixed percentage of an employee's salary to an account with the employee also adding funds to the account. The decision of how to invest that money and the risk of performance are borne by the employee. Upon retirement, the employee uses the funds from this account to fund his or her retirement (McGill, Brown, Haley \& Schieber, 2005).

\section{Employee Benefits, Retirement Plans, and Management Practice}

Employee benefits account for over $30 \%$ of the total compensation cost for employers in the US (US Department of Labor, 2008), and a pension plan is generally considered to be a fundamental component of an employee benefit plan. Research on the importance of compensation to employee and organizational outcomes has indicated clear relationships with employee performance, withdrawal, lateness, absences, and turnover (Currall, Towler, Judge, \& Kohn, 2005). As noted by Heneman and Judge (2000) "Research has unequivocially shown that pay dissatisfaction can have important and undesirable impacts on numerous employee outcomes" (p. 85). Although research that specifically focused on the longitudinal behavioral impacts of pension plan funding as a form of employee compensation is generally lacking, there exists a fair amount of literature indicating the critical importance of employee benefits to human resource (HR) outcomes, including organizational citizenship behavior, job satisfaction, and intention to remain with an organization. For example, using social exchange theory, Lambert (2000) found that enhanced organizational citizenship behaviors resulted from the provision of valued benefits programs by employers. Valued benefit offerings led employees to increase the frequency of helping behaviors at work by providing voluntary creative behaviors such as submitting suggestions for product and process improvements, and through enhanced attendance at quality meetings. Research by Lane (1993) found that satisfaction with benefits was a predictor of intention to leave an 
organization. Williams, Malos, and Palmer (2002) found that job satisfaction was a result of satisfaction with employee benefits. Similarly, Covin et al. (1993) concluded that benefit satisfaction had a favorable influence over a wide range of workplace attitudes and behaviors.

Benefits are of value to employees if they meet employees' needs and preferences (e.g., Dencker, Joshi, and Martocchio, 2007; Dreher, Ash, and Bretz, 1988; Grover and Cooker, 1995; Rappaport, 2004; Wilson, Northcraft, and Neale, 1985). Hence, practicing managers need to be aware of the needs of their particular workforce and provide benefits accordingly. Benefits that do not meet employees' needs will not result in the expected and desired HR outcomes. Therefore, in deciding if and what kind of retirement plan to offer, employers need to carefully consider the benefits to their particular workforce associated with different plans as well as the cost. And the increasing proportion of older workers in today's workforce increases the saliency of pensions as an increasingly valued form of benefits. Age is clearly related to the importance of employee benefits in general and retirement benefits in particular (Dencker, Joshi, and Martocchio, 2007). Therefore, relative to other non-mandatory benefits such as vacation time, retirement benefits are of increasing importance to managing an aging workforce.

\section{A Strategic Perspective on Employee Benefits}

Viewed from a strategic management standpoint, we find similar arguments for the importance of benefits as a tool and source of competitive advantage for organizations. The resource-capability based view of the firm suggests that firms build competitive advantage and earn excess returns when in the possession of valuable and unique resources (Barney, 2002). In this view, human resources refer to the accumulated stock of knowledge, skills, and abilities that the employees possess, which the firm has built up over time into an identifiable expertise which contributes to the firm's strategic objectives. Human skills that are valuable, rare, have a high degree of firm-specificity and low mobility and are imperfectly imitable are a source of added value to the firm. Research in this area has shown that firm-specific skills acquired through long-term onthe-job training have been found to be associated with higher economic returns (Bishop, 1991; Castanias and Helfat, 1991). This resource-based strategic view of human resources suggests that firms should develop policies and practices to prevent a loss of such value.

In summary, we argue that the research clearly asserts that employee benefits are related to important HR outcomes, can serve as a source for higher levels of individual performance, and as a strategic resource providing a competitive advantage to organizations. Thus, managers should view benefits (and pension plans) as a strategic asset to be managed in the same vein as a brand name or research and development capability. Neuberger (2005) writes:

Discussion of occupational pensions has been obscured by emotive language about good employers offering generous pension schemes designed to recruit 
and retain loyal and able employees; the government has talked about the principles of voluntarism as if employers provide pensions out of some sense of public duty. This is sentimentalism that dangerously masks reality. The true cost of providing a DB pension (after stripping out bogus arguments and offsetting investment returns) is at least 20 per cent of salary. Companies bear that sort of cost only if there is good reason to do so, and not out of public duty (pg. 367).

Viewed in this frame the fundamental questions that employers must address with regard to pensions are: (1) what does the pension plan cost and (2) what is the strategic benefit of this investment? While evaluating the cost difference between a DB and DC pension plan is straightforward, evaluating the change in strategic human resource benefits is not. For example, DC plans provide enhanced portability, involvement in investment decision-making, and frequent feedback on fund performance which may result in higher levels of motivation, improved attitudes, and increased performance of employees (Westerman and Sundali, 2005). However, it is also possible that the fluctuations in the value of the DC plans and the variability of the expected cash flows may have powerful negative effects on employee perceptions of the value of this retirement benefit. Employees subscribed to DC plans may experience increased financial anxiety and have greater concern that they are not financially prepared for retirement (Westerman and Sundali, 2005). Employers should consider whether the benefits gained from the shift to DC plans exceed the associated costs in a larger, more strategic sense. For example, providing the enhanced employee mobility inherent in DC plans may lead to the unintended consequence of increasing employee turnover amongst the firm's most experienced, skilled, and valued employees and reducing a firm's human resource-based competitive advantage.

Komoche (1996) notes that "... building an HR capability based on retention capacity is a preliminary step in the creation of HR strategic assets" (p. 217), and suggests that deferred compensation such as pensions can be an effective tool in this regard. However, competitive pressures and accounting/financial cost considerations are arguably the primary forces in the design of a firm's benefits plan, with little consideration given of the potential impact on the firm's human resource-based strategic competitive advantage. Hence, the massive shift from DB to DC plans in organizations in the U.S. over the past 20 years, we argue, is occurring without a great deal of consideration as to its larger strategic impacts beyond short-term accountingbased cost savings. In fact, it appears that practicing managers may not be aware of the potential negative effects on employee attitudes and behaviors associated with the shift from DB to DC plans. We do not suggest that this shift needs to be reversed but rather encourage practitioners as well as scholars to thoroughly explore the positive and negative aspects of both types of plans.

In summary, retirement plans represent an important strategic asset. In the following section, we explore the data from the HRS (Health and Retirement Study, 2004) focusing on respondents' perceptions of different types of retirement plans, their concerns about income during retirement, and their satisfaction in retirement. This exploratory analysis of the data is designed to deepen and build on our understanding 
of what retirees (and hence employees) want in a pension plan. According to Behrens (1997), research is considered "exploratory" when an attempt is made to determine a "best" set of variables or the "best" model for a sample rather than testing a specified model for a specific population. Tukey (1977: 3) emphasizes that "exploratory data analysis can never tell the whole story, but nothing else can serve as the foundation stone - as the first step." Our analysis takes this first step and builds a model to suggest the underlying variables that impact how pension plans contribute to retiree satisfaction. This knowledge can then begin to serve as a framework for employers who desire to use pension plans as an effective strategic benefit for employees. Understanding more about the positive aspects as well as the cost associated with different types of retirement plans allows the practicing manager to make sound decisions when designing a benefits program.

\section{The Health and Retirement Survey}

The HRS (University of Michigan, 2004) began in 1992 and surveys more than 22,000 Americans over the age of 50 every two years. HRS is funded primarily by the National Institute on Aging with supplemental support from the Social Security Administration. The study tracks America's elderly on dimensions such as physical and mental health, insurance coverage, financial status, family support systems, labor market status, and retirement planning. The survey is conducted by the Survey Research Center which is part of the Institute for Social Research at the University of Michigan. The data analyzed and reported in this paper come from a streamlined version of the larger HRS data set prepared by the RAND Corporation (RAND, 2004). The RAND HRS Data file is an easy to use longitudinal data set based on the HRS data. It was developed at RAND with funding from the National Institute on Aging and the Social Security Administration.

\section{Concerns about Retirement.}

We first examine the perceived importance of worry about retirement in general. In the first wave (W1) of the HRS survey (but not in subsequent waves) respondents were asked: "Now for some things people worry about retirement. Please tell me if they worry you a lot, somewhat, a little, or not at all: Not having enough income to get by." As seen in Figure 1, the most frequent response to this question was that they "worry a lot" about not having enough income to get by. Fifty-nine percent of respondents worried a lot or somewhat, and only $41 \%$ reported to worry only "a little" or "not at all." Less than $20 \%$ of respondents reported no worry at all.

Figure 2 displays responses to the worry question as a function of whether the respondent reported having a pension plan on their current job. Sixty-three percent of respondents who reported no information about a pension on their current job indicated they were worried a lot or somewhat about having enough income in retirement, while only $49 \%$ of those who reported 2 or more pensions on the current job reported equivalent levels of worry. Thus, possession of a pension plan seems to provide less worry on the part of subjects in regards to their retirement. 
Figure 1

Concern Regarding Having Enough Retirement Income

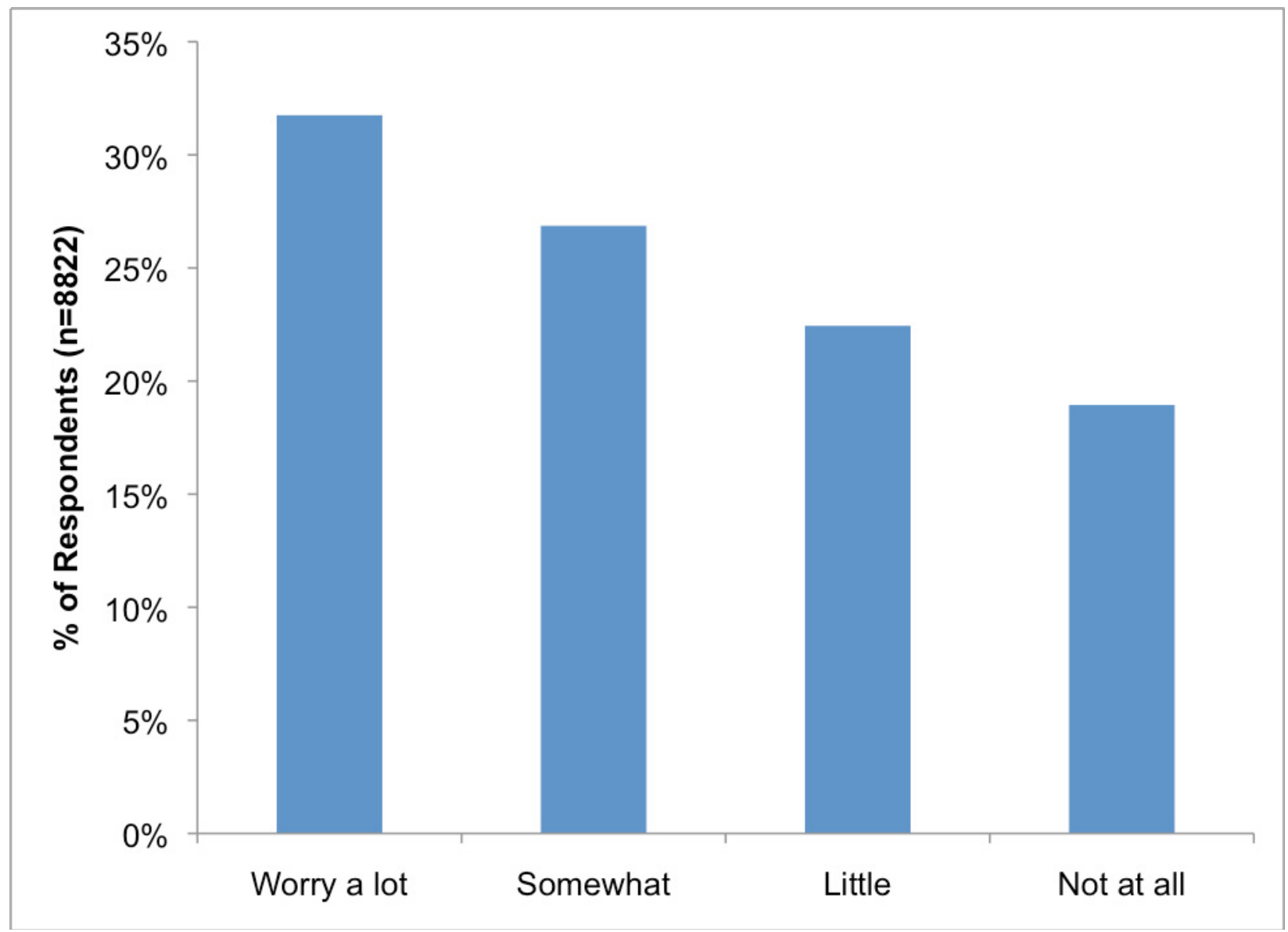


Figure 2

Level of Worry Regarding Retirement Income With and Without Pension

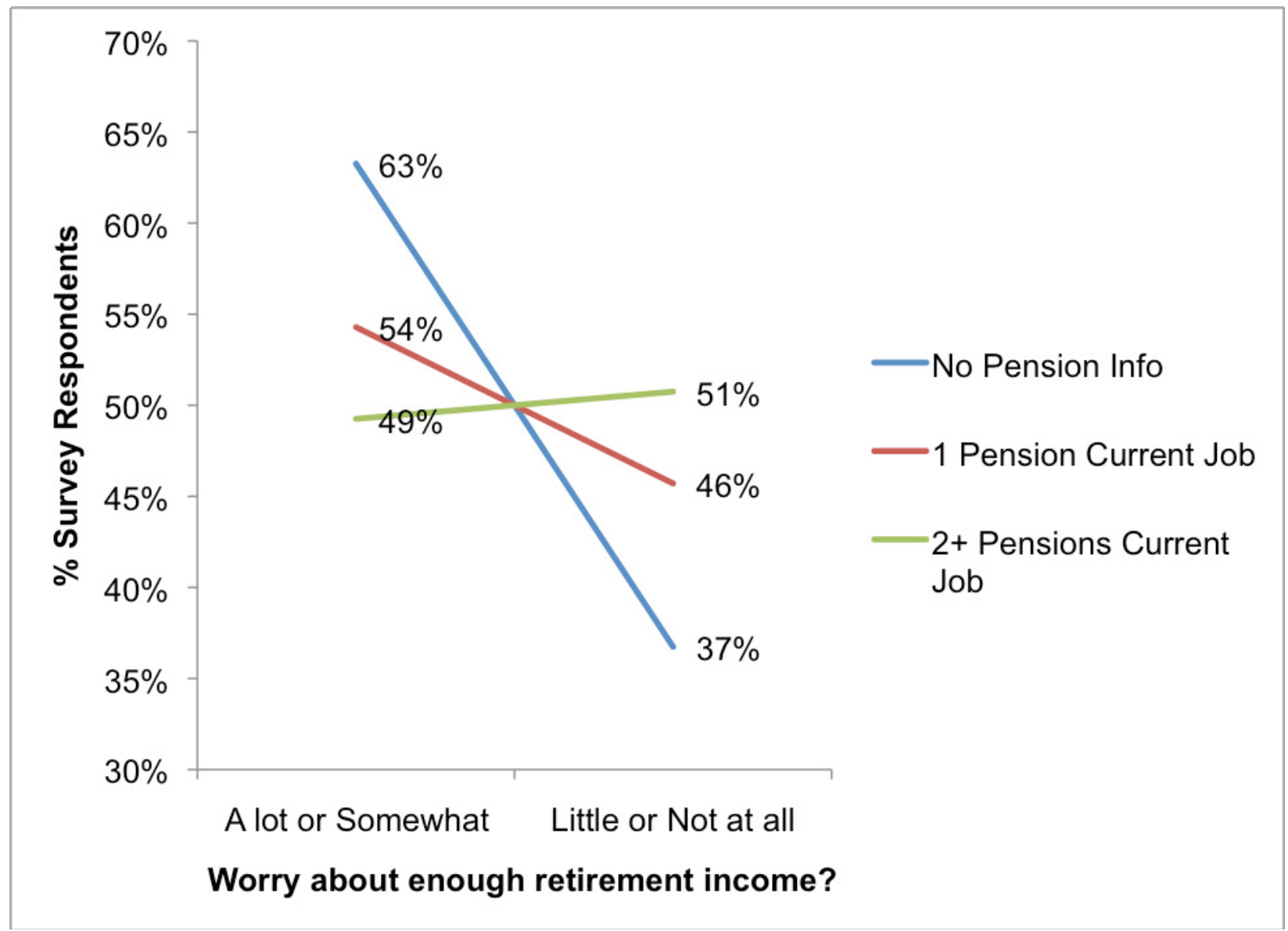


Figure 3

Level of Worry Regarding Retirement Income Contingent on DB or DC Pension

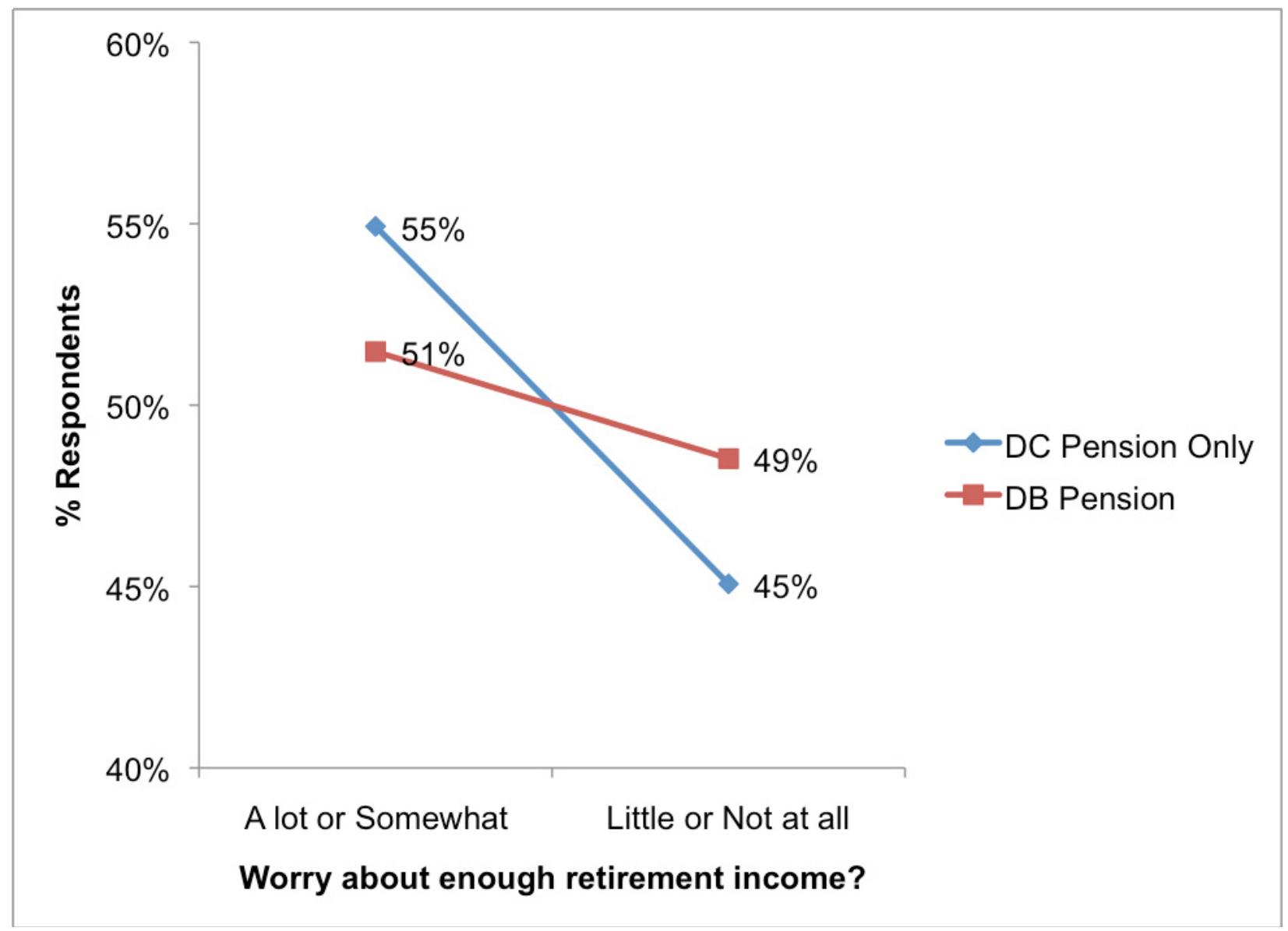


In Figure 3, we examine the level of worry by those who reported having a DB or a DC plan. The data indicated lower levels of worry among those having a DB plan, as $49 \%$ of respondents who reported having a DB pension plan at their current job had little or no worry regarding having enough income in retirement compared to $45 \%$ who had a DC pension plan, and $55 \%$ of DC plan respondents reported worrying "a lot or somewhat" as opposed to $51 \%$ for those in a DB plan.

We then adopted a 12-year longitudinal view which tracked the subjects (prior to and after their retirement) to examine the stability of retirement satisfaction of respondents who answered the worry question. Respondents in Wave 1 of the HRS survey who were asked the worry question were asked in each subsequent wave (every two years) for a self report measure of retirement satisfaction. As shown in Figure 4, the more worried a respondent was about having enough income in retirement in Wave 1, the less satisfied he/she was in retirement. For those most worried about having enough income to get by there is some improvement in retirement satisfaction over time, while retirement satisfaction is high and relatively stable for those who are less worried.

Figure 4

\section{Retirement Satisfaction by Pre-Retirement Worry}

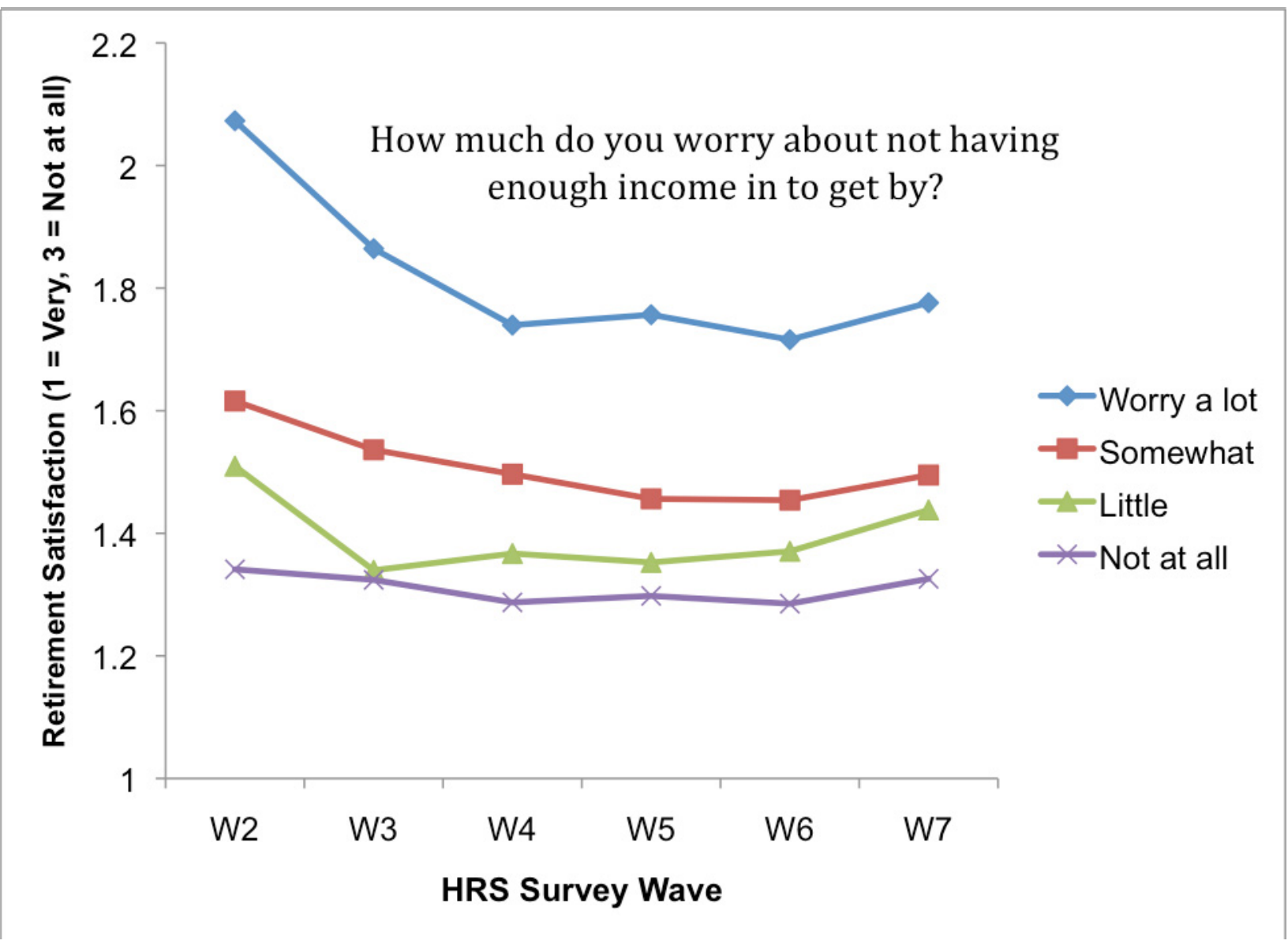


These results lead us to explore the factors that may affect the tendency to worry about income in retirement that are unrelated to one's pension. As could be expected, respondents' worry about having enough income in retirement is related to their health, total household income, and total household assets; with lower levels of each providing for higher levels of worry. These results are shown in the top panels of Table 1.

\section{Table 1}

Retirement Worry by Health, Income and Assets

\begin{tabular}{ccc}
\hline $\begin{array}{c}\text { Self Report of } \\
\text { Respondent } \\
\text { Health: }\end{array}$ & $\mathbf{N}$ & $\begin{array}{c}\text { Worry } \\
(\mathbf{1}=\mathbf{A} \text { lot, } \\
\mathbf{4}=\text { Not at all) }\end{array}$ \\
\hline Poor & 499 & 1.64 \\
Fair & 1133 & 1.99 \\
Good & 2564 & 2.26 \\
Very Good & 2581 & 2.39 \\
Excellent & 2045 & 2.50 \\
\hline
\end{tabular}

\begin{tabular}{cccc}
\hline $\begin{array}{c}\text { Total Household } \\
\text { Income Greater } \\
\text { Than or Equal } \\
\text { To: }\end{array}$ & $\begin{array}{c}\text { Total Household } \\
\text { Income Less } \\
\text { Than: }\end{array}$ & $\mathbf{N}$ & $\begin{array}{c}\text { Worry } \\
\mathbf{1}=\mathbf{A} \text { lot, }\end{array}$ \\
$\mathbf{4}=$ Not at all)
\end{tabular}


Table 1 cont.

\begin{tabular}{|c|c|c|c|}
\hline $\begin{array}{c}\text { Total Household } \\
\text { Assets Greater } \\
\text { Than }\end{array}$ & $\begin{array}{l}\text { Total Household } \\
\text { Assets Less } \\
\text { Than }\end{array}$ & $\mathbf{N}$ & $\begin{array}{c}\text { Worry } \\
(1=\text { A lot, } \\
4=\text { Not at all })\end{array}$ \\
\hline & $\$ 29,800$ & 1827 & 1.89 \\
\hline$\$ 29,800$ & $\$ 89,000$ & 2204 & 2.20 \\
\hline$\$ 89,000$ & $\$ 203,000$ & 2211 & 2.40 \\
\hline$\$ 203,000$ & & 2206 & 2.69 \\
\hline $\begin{array}{l}\text { Total Assets I } \\
\text { Total Income }\end{array}$ & $\begin{array}{l}\text { Average Total } \\
\text { Household } \\
\text { Asset }\end{array}$ & $\begin{array}{l}\text { Average Total } \\
\text { Household } \\
\text { Income }\end{array}$ & $\begin{array}{c}\text { Worry } \\
\text { (1 = A lot, } \\
4 \text { = Not at all) }\end{array}$ \\
\hline$<0$ & $\$(12,271)$ & $\$ 20,280$ & 1.78 \\
\hline $0-1$ & $\$ 24,692$ & $\$ 45,475$ & 2.06 \\
\hline $1-2$ & 84,607 & $\$ 56,068$ & 2.28 \\
\hline $2-3$ & $\$ 140,464$ & $\$ 56,823$ & 2.40 \\
\hline $3-4$ & $\$ 193,191$ & $\$ 55,791$ & 2.42 \\
\hline $4-5$ & $\$ 243,378$ & $\$ 54,396$ & 2.45 \\
\hline $5-6$ & $\$ 270,047$ & $\$ 49,143$ & 2.40 \\
\hline$>6$ & $\$ 609,774$ & $\$ 48,219$ & 2.51 \\
\hline
\end{tabular}

We explored the effects of pension income on worry in further detail. Prior research (Easterlin, 2001) has suggested that material expectations are often proportional to income. If we assume that financial expectations are proportional to income then one's income prior to retirement is a proxy for one's expectations in retirement. To measure this, we divided total household assets by total household income for each respondent, creating a net asset/income ratio (NAI) shown at the bottom of Table 1. This ratio is a measure of whether one's net worth is capable of supporting one's financial 
expectations (assuming expectations are proportional to income). The data suggest that the amount of worry is proportional to NAl, and those whose total assets are low relative to their income worry more about having enough income to get by in retirement. An interesting finding is that the least worried are not those who have the highest income prior to retirement, but those whose net worth is the highest multiple of their preretirement income.

\section{$\underline{\text { Retirement Satisfaction }}$}

We then focused our analyses solely on post-retirement respondents to examine the stability of retirement satisfaction. In all waves of the survey (covering 1992 to 2004) respondents were asked "All in all, would you say that your retirement has turned out to be very satisfying, moderately satisfying, or not at all satisfying" (1=very, 2=moderately, $3=$ not at all). The results from this question are shown in Figure 5.

The majority of the respondents report that they are very or moderately satisfied, and a minority $(6 \%-20 \%)$ report being not at all satisfied. The percentage of retirees who report being very satisfied in retirement shows an increase from $44 \%$ in Wave 1 $(n=1,787)$ to $61 \%$ in Wave $6(n=6,992)$, with a decline to $55 \%$ in Wave $7(n=8,324)$. The mean satisfaction response steadily increases from 1.77 to 1.49 from Wave 1 to wave 6 , and then falls to 1.54 in Wave 7 . Table 2 summarizes the within subject change in retiree satisfaction from one wave to the next. Seventy percent of subjects report no change in retirement satisfaction from one wave to the next, while $16 \%$ report an increase in satisfaction and $14 \%$ report a decrease. Thus, individual respondents' satisfaction in retirement appears to be rather stable over time.

A question that is asked of all respondents who report that they are completely retired is to compare their perception of quality of life in their years just before retirement to their retirement years as being better, about the same, or not as good. Figure 6 shows these results. Less than half of the respondents report that their retirement years are better than just before retirement, with the rest reporting that retirement is about the same or not as good compared to before their retirement. 
Figure 5

Overall Retirement Satisfaction by Survey Wave

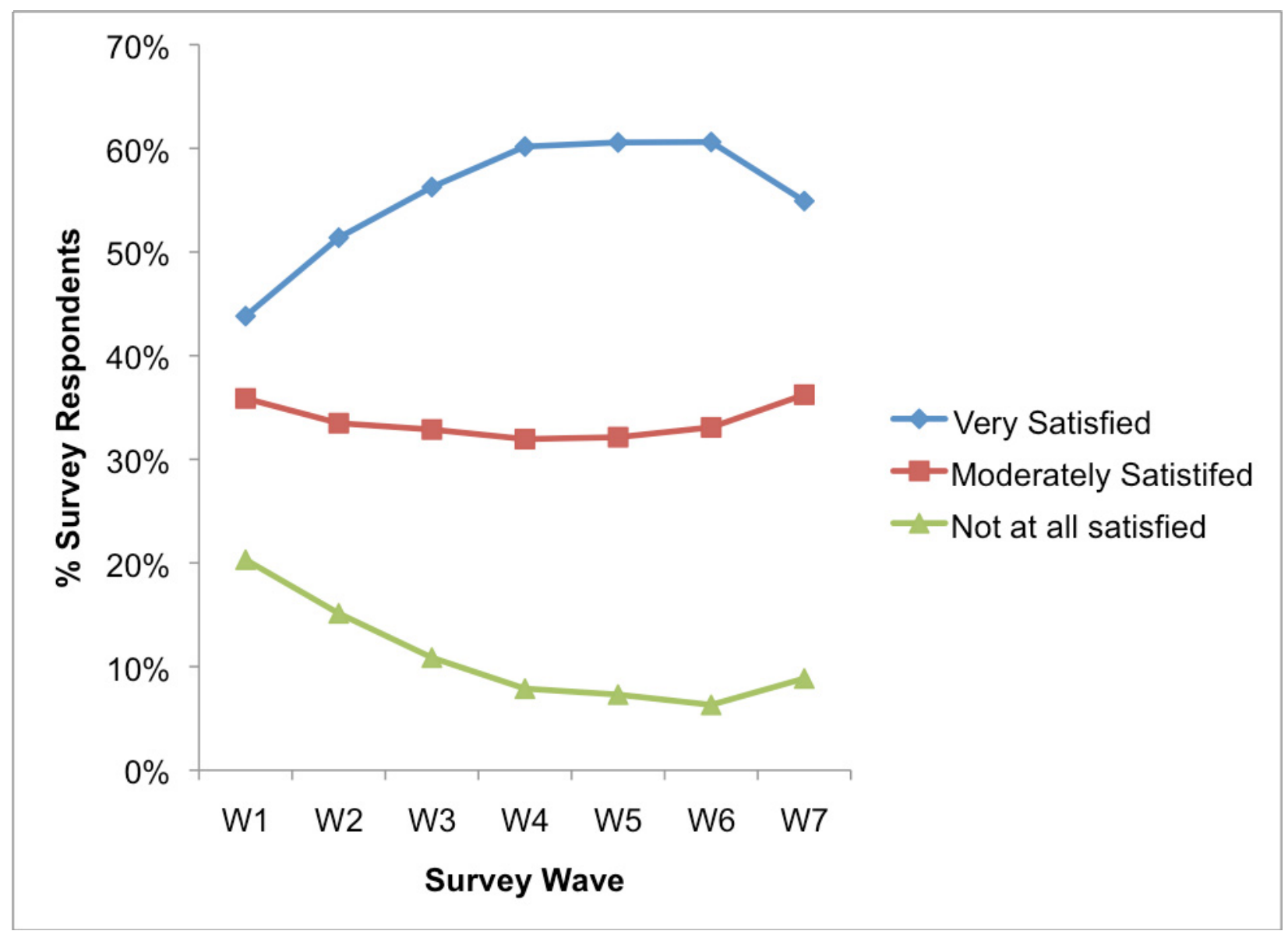


Table 2

Change in Retirement Satisfaction from Wave $n$ to Wave $n+1$

\begin{tabular}{|c|c|c|c|c|c|c|}
\hline & & & Wave $n+1$ & & & \\
\hline & & $\begin{array}{l}\text { Very } \\
\text { Satisfied }\end{array}$ & $\begin{array}{l}\text { Moderately } \\
\text { Satisfied }\end{array}$ & $\begin{array}{l}\text { Not at all } \\
\text { Satisfied }\end{array}$ & Total N & $\begin{array}{l}\text { Row } \\
\text { Percent }\end{array}$ \\
\hline & $\begin{array}{l}\text { Very } \\
\text { Satisfied }\end{array}$ & 9371 & 2109 & 164 & 11644 & $61 \%$ \\
\hline Wave & $\begin{array}{l}\text { Moderately } \\
\text { Satisfied }\end{array}$ & 1878 & 3486 & 505 & 5869 & $31 \%$ \\
\hline$n$ & $\begin{array}{l}\text { Not at all } \\
\text { Satisfied }\end{array}$ & 159 & 952 & 594 & 1705 & $9 \%$ \\
\hline & Total N & 11408 & 6547 & 1263 & 19218 & $100 \%$ \\
\hline & $\begin{array}{l}\text { Column } \\
\text { Percent }\end{array}$ & $59 \%$ & $34 \%$ & $7 \%$ & $100 \%$ & \\
\hline
\end{tabular}

Change in Retirement Satisfaction from Wave $n$ to Wave $n+1$

$\begin{array}{ll}\text { Better } & 16 \% \\ \text { Same } & 70 \% \\ \text { Worse } & 14 \%\end{array}$


Figure 6

Retirement Years Compared to Before Retirement

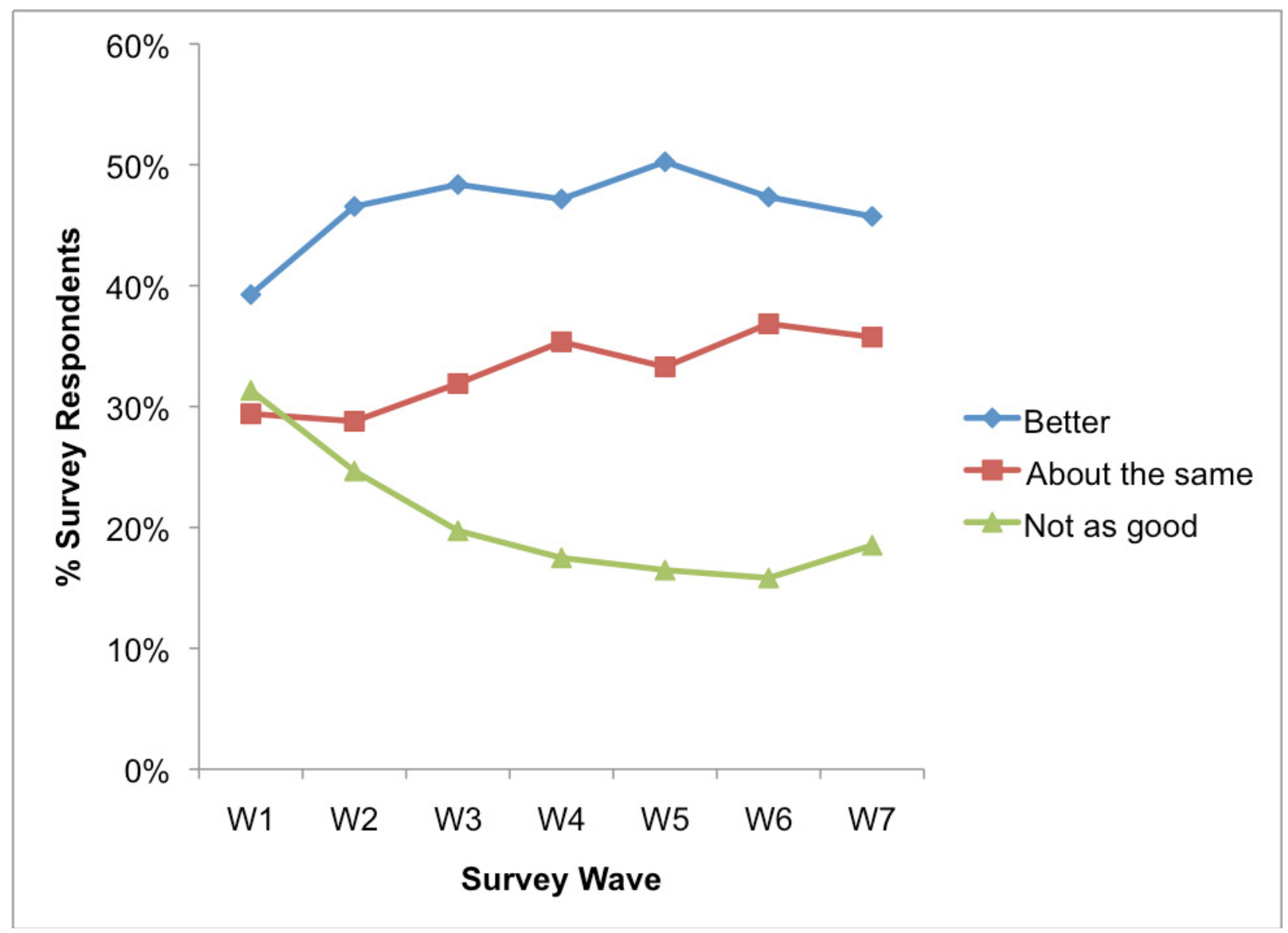

What are the factors that may be related to retiree's perception of the quality of their retirement years? Prior research using cross-sectional analysis limited to one wave of HRS data provides interesting insights. Pantis (2004) found that retirees reported higher levels of satisfaction when they had guaranteed income streams (as in DB plans), and reported that retirees with household income of between $\$ 15,000$ and $\$ 30,000$ with a DB pension were just as likely to be very satisfied in retirement as retirees with income above $\$ 50,000$ with no guaranteed pension income. Bender and Jivan (2005) similarly found that the effect of having a guaranteed pension income on retirement satisfaction was fairly large and statistically significant.

Pantis (2004) and Bender and Jivan (2005) conducted cross sectional analyses that were limited to one wave of HRS data. We replicated their basic findings using data from all waves of HRS data. We first examined the effects on retirement satisfaction if the household was receiving a pension income. These results are reported graphically in Figure 7. The magnitude of the importance on retirement satisfaction of a pension income is quite large. 
We then conducted a more in-depth analysis, with the following independent variables used as predictors of retirement satisfaction:

- Household Total Assets - the net value of total wealth is calculated as the sum of all wealth components less all debt

- Household Total Income - the sum of all income in the household

- Respondent and Spouse Health - self-report measure of general health

- Household DB Pension - set to yes if anyone in the household reported having a DB pension while working

Table 3 reports the results from this analysis using the most recent wave of HRS data available (W7, 2004) using an ordered LOGIT model and an OLS regression model. As expected, a positive correlation exists between retirement satisfaction and the level of total household assets, total household income, the quality of the self reported health of the primary respondent and spouse. Further, after controlling for wealth, income, and health, retirement satisfaction is higher if anyone in the household reported having a DB pension while working. These basic results were replicated across all waves of the HRS data.

\section{HRS Analysis Summary and Conclusions}

The data from the HRS survey indicate that prior to retirement respondents are worried about having enough income to get by in retirement. The level of worry is reduced if a respondent's income and net worth is higher, their health is better, and if the respondent has or lives in a household that has a pension. Once in retirement, a little more than half of retirees report being very satisfied with the rest reporting moderate or low levels of retirement satisfaction. About half of retirees report that retirement is better than before retirement, and half report it to be about the same or worse than before.

Satisfaction levels in retirement appear to remain relatively stable over time. Finally, retirement satisfaction appears positively correlated with income, net worth, and health, and retirement satisfaction is positively related to having access to annuitized income and may decline without such stable income streams.

There are several findings from this data exploration that we find most interesting and important to managers and to future research. First, there does not appear to be a direct relationship between income and retirement satisfaction. The data suggest that respondents who report the lowest levels of worry are not those who have the highest income prior to retirement, but those whose net worth is the highest multiple of their preretirement income. This finding may suggest that those whose expectations are modest (based upon their income level) relative to their asset base are the most satisfied. 
Figure 7

Retirement Satisfaction by Presences of Household Pension

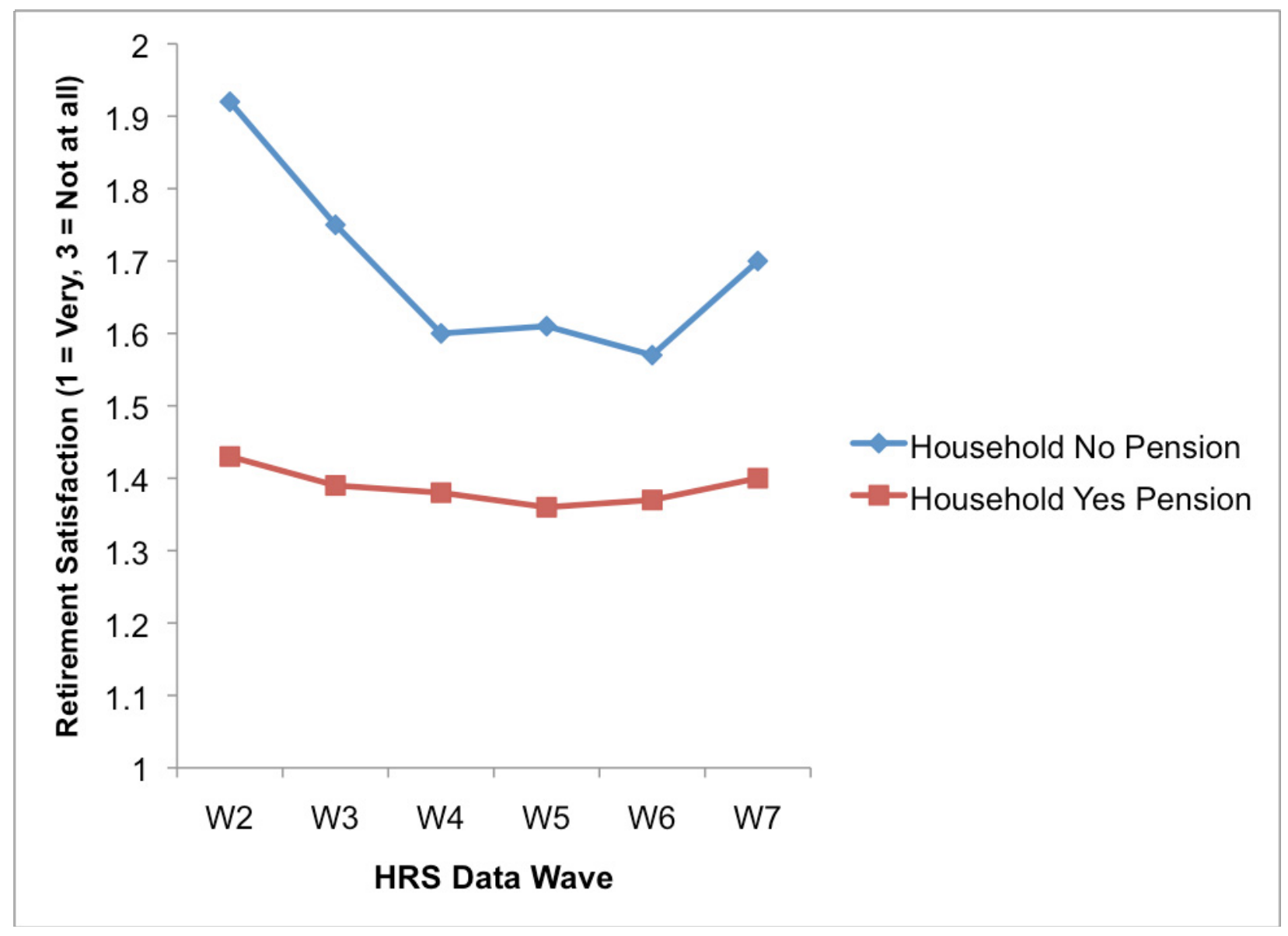


Table 3

Logistic and OLS Regressions of Retirement Satisfaction

HRS Wave 7 (2004)

\begin{tabular}{lcr}
\hline & Logistic & OLS Regression \\
\cline { 2 - 3 } Intercept 1. Very & $2.32^{* *}$ & \\
Intercept 1. Moderately & $4.72^{* *}$ & $0.92^{* *}$ \\
Intercept & & $0.00000003^{* *}$ \\
Total of all Household Assets & $0.0000003^{* *}$ & $0.00000003^{* *}$ \\
Total Household Income & $0.000002^{*}$ & $0.18^{* *}$ \\
Self Report of Respondent Health & $-0.063^{* *}$ & $0.06^{* *}$ \\
Self Report of Spouse Health & $-0.21^{* *}$ & $0.02^{* *}$ \\
Household DB Pension & $0.71^{* *}$ & 5011 \\
\cline { 2 - 2 } $\mathrm{N}$ & & 0.18 \\
\hline R-Square & 5011 & \\
\hline$* \mathrm{p}<0.05$ & & \\
$* * \mathrm{p}<0.01$ & & \\
\hline
\end{tabular}

The second interesting conjecture that emerges from the data is the importance of annuitized income streams, such as those found in DB pension plans. Pre-retirement worry and post-retirement satisfaction are improved if annuitized income streams exist. This suggests that not only is the level of income and assets important, but the type of income is also an important consideration. Building on these conjectures, we introduce a theoretical framework in an attempt to explain these results on retiree satisfaction and the importance of DB pension plans to managers and organizations.

\section{Income and Happiness}

At a macro-economic level, the well-being of citizens in a country is often measured by per capita GNP, but many economists believe this income measure is imperfect or insufficient (Erikson, 1993; Frank, 2008). Oswald (1997) and Easterlin (2001) have reviewed years of subjective data on happiness and objective data on income and both 
conclude that although objective income has increased, there has been only a slight reported increase in subjective happiness. Oswald (1997) notes that real income has steadily and substantially risen in both the United States and Europe since World War II, in fact doubling or tripling in some countries, and yet measures of happiness have only increased slightly and may not be attributable to income at all. On a micro level, Easterlin (2001) found that on a cross sectional basis there was a consistent and significant positive correlation between income and happiness; for example, using 1994 data from the United States, the simple correlation between income and happiness was 0.20 . But when cohort groups were tracked on a longitudinal or life cycle basis, there was little support for the contention that happiness kept pace with increases in income across the life cycle. These findings suggest that relative income may be more important than absolute income.

To account for these findings a theory of adaptive expectations has been put forth (Sen, 1987; Easterlin, 2001; Burchardt, 2005). It asserts that people evaluate their happiness relative to the situation they find themselves in and the aspirations and expectations that have set for themselves. An example of this phenomenon has been described by Sen (1987) who noted that someone who has never known anything other than material deprivation may not be unhappy or dissatisfied with his/her circumstances: "The battered slave, the broken unemployed, the hopeless destitute, the tamed housewife, may have the courage to desire little.... the materially deprived individual could be at the same point in the distribution of well-being as someone who achieves the same degree of happiness with four holidays a year and a sports car" (Sen, 1987, p. 11). Easterlin (2001) has suggested that material aspirations change over the life cycle roughly in proportion to income. Thus, as income increases there is no subjective increase in reported happiness because material expectations have risen to reflect their level of income.

Nobel laureate Amartya Sen has proposed the idea of capability and well-being to further elucidate an understanding of happiness. Nussbaum and Sen (1993) explain the concept of capabilities as:

The life that a person leads can be seen as a combination of various doings and beings, which can generically be called functionings. These functionings vary from such elementary matters as being well nourished and disease-free to more complex doings or beings, such as having self-respect, preserving human dignity, taking part in the life of the community, and so on. The capability of a person refers to the various alternative combinations of functionings, any one of which (any combination, that is) the person can choose to have. In this sense, the capability of a person corresponds to the freedom that a person has to lead one kind of life or another (pg. 3).

The capabilities framework proposes that individual well-being is correlated with the set of functionings possessed. Functionings make up a person's being, and to evaluate well-being one must take account of the set of functionings or capabilities that extend or limit an individual's opportunity set. Within this framework Sen (1993) makes a 
distinction between (1) achievement, and (2) freedom to achieve. Well-being is not only related to the actual achievements realized from one's capabilities, but also derives from the freedom one experiences based upon the set of real opportunities available. That is, capabilities matter not only because they give us well-being achievement but also because they give us well-being freedom.

\section{Capabilities, Adaptive Expectations, and Pension Plans}

Our examination of the HRS data and review of the literature lead us to propose that well-being or happiness in retirement is contingent upon both capabilities and resources $(\mathrm{CR})$ and adaptive expectations (AE) - see Table 4. We suggest there are two primary determinants of well-being in the CR/AE framework. First, well-being is positively correlated with the absolute level of capabilities. Second, well-being is influenced by the extent to which one's expectations are fulfilled. Well-being is highest for those with many capabilities whose expectations have been fulfilled. Those with low capabilities but whose expectations have been fulfilled will experience a moderate level of well being. Those with many capabilities but whose expectations are unfulfilled will experience variable well-being; for example, these individuals may have high income and wealth but their material aspirations exceed their financial ability to fulfill them. Well-being is lowest among those with few capabilities and unfulfilled expectations.

Table 4

Well-Being Contingent on Adaptive Expectations and Capabilities

\begin{tabular}{ccc}
\hline & \multicolumn{2}{c}{ Capabilities/Resources (CR) } \\
\cline { 2 - 3 } $\begin{array}{c}\text { Adaptive Expectations } \\
\text { (AE) }\end{array}$ & Many & Few \\
\cline { 2 - 3 } Expectations Fulfilled & High Well-Being & Moderate Well-Being \\
Expectations Unfulfilled & $\begin{array}{c}\text { Moderate and Unstable } \\
\text { Well-Being }\end{array}$ & Low Well-Being \\
\hline
\end{tabular}

To apply this framework to the relationship between pension plans and employee and retiree well-being, consider first employees enrolled in traditional DB plans. Since most DB pensions promise to provide a fixed percentage of salary in retirement, these employees will know prior to retirement what their income stream will be once in retirement. This knowledge allows DB retirees to accurately estimate their level of financial capabilities and set their retirement expectations accordingly. Given the stability of DB pensions, once in retirement these employees are not likely to have major income surprises and therefore will be less likely to have to forego any expectations that have been set. Thus, an employee with a DB pension plan, irrespective of the absolute level of the pension, will experience at least a moderate 
level of well-being by being able to live in accordance with one's expectations (expectations fulfilled). Clearly, well-being will be higher the greater the absolute level of the pension since it allows for the attainment of more functionings and capabilities. These employees also experience less anxiety prior to retirement since they set their expectations with the knowledge they have the financial means to fulfill them.

Assessing the relationship between DC pensions and well-being is more complicated. The absolute value generated in a DC pension depends upon the level of employee/employer contributions and, more importantly, the level of investment returns earned. As such, the wealth created from a DC pension plan can be significantly higher or lower than that generated in a DB pension plan. Since the values of DC pensions vary depending upon investment returns, DC employees will encounter greater uncertainty in attempting to estimate their cash flows in retirement. As a result, DC employees may encounter significant difficulty in determining appropriate expectations for retirement. Once in retirement, given the variability in market returns, DC pension plans are more likely to provide income above or below what the employee expected. If the amount of income is below expectations, we should expect lower levels of wellbeing. However, even if income is above expectations, well-being may still be lower. It may be perceived that the fulfillment of one's expectations may be temporary, and subject to the uncertainty and whims of the market and one's investments. Further, if one's investments consistently create more capabilities than expected, the employee has the difficulty of determining the years of life with which to budget an appropriate cash flow to maximize their retirement, and may experience frustration or dissonance in that they have been living below what they could have been and didn't set higher expectations earlier to live a fuller retirement.

Research on subjective well-being indicates that instability in life circumstances and general environmental factors is associated with low mean levels of well-being and that remaining in one stable state or condition for a long time has less impact than moving from state to state in that it offers the individual the sense of security and control (Fujita \& Diener, 2005). Thus, in general we expect the instability of DC plans to lower wellbeing due to expectation uncertainty. However, absolute levels of wealth may outweigh expectation uncertainty - and thus individuals with bountiful DC plans may experience at least moderate well-being.

Burchardt (2005) provides evidence consistent with these conjectures. Using ten years of panel data from the British Household Panel Survey, it was found that individuals who experienced a decline in income from the previous year are less satisfied than those who experienced a steady income, suggesting that subjective assessments are made in comparison with previous experience. Burchardt notes that "Over the longer run, for the same outcome in terms of level of income, those who have experienced rising incomes do not experience greater satisfaction than those who have had constant incomes, while those who have experienced falling incomes are significantly less satisfied. Subjective responses to increases and decreases in income therefore appear to be asymmetric; this finding is consistent with Kahneman and Tversky's prospect theory (1979)." 
The prospect theory explanation is straightforward. Prospect theory suggests that positive and negative changes in income are not evaluated equally from a fixed referent point. Specifically, the increase in happiness for a $\$ 100$ gain in income is not equivalent to the decrease in happiness from a $\$ 100$ loss in income (Kahneman \& Tversky, 1979). If one's expectations consistently rise to the level of income, a variable income stream means that income will either be above, equal to, or below the amount necessary to meet material expectations at any given point in time. And since losses hurt more than gains, the experience of having income below expectations will have a greater impact than income above expectations.

In summary, living consistent with one's expectations is a critical factor in well-being. Unstable incomes are subjectively less satisfactory than stable ones, and this dislike of uncertainty suggests that individuals' beliefs about the future play an important role in the subjective evaluation of income. Well-being is influenced in complex ways that include both an individual's capabilities and expectations. We suggest the model shown in Figure 8 as a summary of the relationship between capabilities, expectations, and well being.

Figure 8

Proposed Relationship Between Capabilities, Expectations and Well-Being

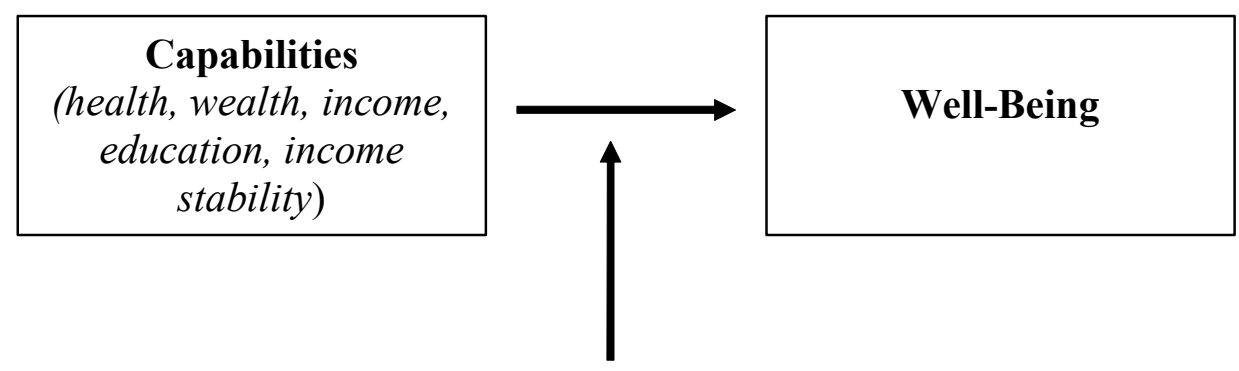

\section{Expectations \\ (material aspirations)}




\section{Discussion}

The primary purpose of this research was to investigate the potential consequences of the major shift away from DB to DC pension plans. Traditional economic theory suggests a straightforward relationship: that more wealth is preferred to less, more income is preferred to less, and that more assets are associated with higher levels of retirement satisfaction. Simply put, the happiest retirees should be the ones with most assets, all other things being equal. Yet, the longitudinal research presented here suggests the relationship is more complicated and that absolute levels of money may not result in the most happiness in retirement.

The data from the HRS support that income stability, as provided by defined benefit retirement plans, contributes to satisfaction both pre- and post-retirement after controlling for individual capabilities including wealth and health. We have suggested a model based on prior theory to explain the mechanisms for this result, namely that "capabilities" and "adaptive expectations" interact to affect retirement expectations and satisfaction. We further speculate that the predictability associated with DB plans allows employees and retirees to have realistic expectations about "what they can do in retirement" which leads them to worry less about having enough income in retirement and to be more satisfied in retirement since their expectations and capabilities are aligned. The proposed theoretical relationship between capabilities, adaptive expectations and retirement satisfaction is consistent with the cross-sectional empirical findings of Pantis (2004) and Bender and Jivan (2005) indicating that the shift from DC to $\mathrm{DB}$ retirement plans may have negative effects on employee and retiree satisfaction.

These results have important implications when considering retirement plans as a strategic resource for managers and their firms. It appears that DC plans are likely to be associated with higher pre-retirement worry and lower retirement satisfaction than DB plans. Thus, if given a choice, many employees may prefer DB over DC plans, creating a potential source of competitive advantage in the labor market for companies that offer DB plans. Employees who are not given a choice but forced to accept a DC plan, which may be the case as more and more employers continue to shift to DC plans, will worry more about retirement. This worry is likely to carry over to current work attitudes, affecting employees' job satisfaction, organizational commitment, intention to leave an organization, and job performance. As a pension plan is a primary component of most employee benefit and compensation strategies, managers should be cognizant of the impact of benefit plan perceptions on employee attitudes and behaviors, as research has indicated that dissatisfaction with benefits affects employee citizenship behaviors (Lambert, 2000), intention to leave (Lane, 1993), job satisfaction (Williams, Malos, \& Palmer, 2002), and a wide range of workplace attitudes and behaviors (Covin, 1993). As a result, shifting from DB's to DC's may result in substantial loss of productivity.

The caveat to these conclusions is that negative effects caused by instability of DC plans may be overcome with enough retirement wealth; put another way, DC employers can overcome instability with generous contributions to the DC plans. However, with 
most employers switching to DC plans to reduce pension liabilities, whether they are willing to provide such generous contributions is an open question.

Given the exploratory nature of this study, the following caveats/limitations have to be considered. We have not provided any direct measures of well-being, material expectations, or pre-retirement worry on employee attitudes and behaviors. These are important tasks for future confirmatory research. Keeping these caveats in mind, our suppositions have interesting implications. First, it seems worthwhile to consider capabilities and adaptive expectations when studying the effects of employee benefits in general. Second, other theoretical approaches should be explored to further our understanding of the effect of DB's and DC's. One potential alternative explanation for the finding that stable income flows seem to be more valued by employees and retirees than overall wealth may be social comparisons (Currall et al 2005). Individuals form judgments of pay satisfaction by comparing their outcome (pay) to input ratio relative to the ratios for comparison others. When an individual's outcome/input ratio is below that of comparison others, the individual may respond by lowering his/her level of effort, thereby bringing the ratio closer to the referent's ratio. If one feels underrewarded, the effects of justice theory on the behavioral implications are well documented. Another potential explanation is from the economic theory of transaction costs. Miceli and Lane (1991) found that more efficient benefit systems were associated with higher levels of benefit satisfaction. This finding was replicated and extended by Williams, Malos, and Palmer (2002). DC plans may lead to a large amount of decision-making and management, which may increase the perceived transaction costs of the plan. Future research should examine the potential influences of organizational justice perceptions and transaction cost analysis on employee outcomes.

\section{Practical Implications}

Practical implications of our findings include that employers should more thoroughly consider the broader impact of the wholesale and precipitous shift currently underway in compensation strategy from DB to DC pension plans in the U.S. Although many employers are moving to $\mathrm{DC}$ plans in a desire to provide greater pension liability control and portability to employees, the primary benefit of DB plans may be the security provided by the stable cash flows. Further, some employers may be shifting towards DC plans to reduce their overall pension expenses; however, such expense-reducing benefits may be offset by the negative attitudinal and behavioral responses which may result from such plans. It is quite possible that employers could offer less generous DB plans, hence reducing the objective cost of the plan that would provide higher subjective benefits to employees than a similarly priced DC substitute. Specifically, these findings support that when comparing DC versus DB plans employers may be making decisions without adequate consideration of costs beyond short-term accounting concerns. Relative to other correlates of HR outcomes, retirement benefits are a critical tool as they are entirely controlled by management and can be adjusted and changed as strategically necessary. As the workforce continues to age, benefits (and more importantly, pension benefits) are increasing in their saliency for employees. Especially in the context of the public debate of challenges related to the Social Security System, 
employees are increasingly aware and concerned with their post-retirement future. Research indicates that employee anxiety and stress about the transition to retirement begins long before retirement (MacEwen, Barling, Kelloway, Higginbottom, 1995), and stress has been shown to affect a variety of employee outcomes including job satisfaction, employee health, and productivity and performance (Fox, Dwyer, \& Ganster, 1993; Jex \& Britt, 2008). Maintaining high levels of productivity among older employees requires that the practicing manager has tools to address anxiety and stress associated with concerns about retirement. Such tools include providing the type of retirement plan most valued by employees. At a minimum, management must be aware of the "hidden" costs in form of anxiety and stress when providing less desirable plans. Finally, research indicates a strong relationship between employee benefits and employees' perception of the employer as concerned with employee well-being. Such perceptions have been shown to be related to employee attitudes and behaviors (e.g., Eisenberger, Jones, Aselage, and Sucharski, 2004). Again, this positive outcome must be considered in evaluating the cost and benefits of different retirement plans.

Providing the "right" benefits communicates to employees that the employer cares about their welfare, which results in improved employee outcomes - a primary concern of any practicing manager.

In summary, the shift from DB to DC benefit plans by employers in the U.S. has been substantial, and the potential effects of this shift have been unexamined in management research. Although exploratory in nature, this study represents the first longitudinal examination of the effects of DB/DC choices on pre- and post-retirement worry and satisfaction. We do not recommend one type of retirement plan over the other, however, we offer a theoretical model to interpret the results of our exploratory analyses (using prior research on adaptive expectations and resources/capabilities) in the hope of providing a greater understanding of the causes and effects of this shift, and to guide future research in this important area of study.

\section{REFERENCES}

Barney, J. (2002). Gaining and Sustaining Competitive Advantage, 2ed. New Jersey: Prentice Hall.

Behrens, J. T. (1997). Principles and Procedures of Exploratory Data Analysis. Psychological Methods, 2, 131-160.

Bender, K.A. \& Jivan, N.A. (2005). What Makes Retirees Happy? Center for Retirement Research at Boston College, 28, 1-8.

Berns, G., Chappelow, J., Cekic, M., Zink, C., Pagnoni, G.\& Martin-Skurski, M. (2006). Neurobiological Substrates of Dread. Science, 312, 754-758.

Bishop, J. (1991). The Impact of Previous Training in Schools and On Job on Productivity, Required OJT, and Turnover of New Hires. Unpublished manuscript, Center for Advanced Human Resource Studies, Cornell University. (Cited in Cappelli \& Singh, 1992). 
The Board of Trustees, Federal Old-Age and Survivors Insurance and Federal Disability Insurance Trust Funds, (2008). The 2008 Annual Report of the Board of Trustees of the Federal Old-Age and Survivors Insurance and Federal Disability Insurance and Trust Funds. (www.socialsecurity.gov).

Burchardt, D. (2005). Are One Man's Rags Another Man's Riches? Identifying Adaptive Expectations Using Panel Data. Social Indicators Research, 74, 1, 57-102.

Castanias, R. \& Helfat, C. (1991). Managerial Resources and Rents. Journal of Management, 17, 155-177.

Covin, T., Kolenko, T., Sightler, K., \& Tudor, K. (1993). Pay and Organizational Effectiveness: Empirical Evidence and Implications for Management Consultants. Academy of Management Best Papers Proceedings 1993, 185-189.

Currall, S., Towler, A., Judge, T., \& Kohn, L. (2005). Pay Satisfaction and Organizational Outcomes. Personnel Psychology, 58, 613-640.

Dencker, J.C., Joshi, A., \& Martocchio J. (2007). Employee Benefits as Context for Intergenerational Conflict. Human Resource Management Review, 17 (2), 208-220

Dreher, G.F., Ash, R.A., \& Bretz R.D. (1988). Benefit Coverage and Employee Cost: Critical Factors in Explaining Compensation Satisfaction. Personnel Psychology, 41, (2), 237-254

Easterlin, R. (2001). Income and Happiness: Towards a Unified Theory. The Economic Journal, 111, July, 465-484.

Eisenberger, R., Jones, J.R, Aselage, J., \& Sucharski, I. (2004). Perceived Organizational Support. In Coyle-Shapiro J. A.-M., Shore, L. \& Taylor, S. (Eds) The Employment Relationship. Oxford, UK: Oxford University Press

Erikson, R. (1993). Descriptions of Inequality: The Swedish Approach to Welfare Research. In The Quality of Life, eds. Nussbaum, M. \& Sen, A., 67-83. Oxford: Clarendon Press.

Fox, M., Dwyer, D., \& Ganster, D. (1993). Effects of Stressful Job Demands and Control on Physiological and Attitudinal Outcomes in a Hospital Setting. Academy of Management Journal, 36(2), 289-318.

Frank, R. (2008). Income and Happiness: An Imperfect Link. New York Times, March 9, Sunday Business, p. 6.

Fujita, F., \& Diener, E. (2005). Life Satisfaction Set Point: Stability and Change. Journal of Personality and Social Psychology, 88(1), 158-164. 
Grover, S. \& Crooker, K.J. (1995). Who Appreciates Family-Responsive Human Resource Policies: The Impact of Family-Friendly Policies on the Organizational Attachment of Parents and Non-Parents. Personnel Psychology, 48 (2), 271-288.

Heneman H. \& Judge, T. (2000). Compensation Attitudes. In Rynes, S. \& Gerhart, B. (Eds.), Compensation in Organizations: Current Research and Practice, 61-203, San Francisco, CA: Jossey-Bass.

Jex, S., \& Britt, T. (2008). Organizational Psychology: A Scientist-Practitioner Approach. 199-231. Hoboken, NJ: John Wiley \& Sons.

Kahneman, D., \& Tversky, A. (1979). Prospect Theory: An Analysis of Decision Under Risk. Econometrica, 47(2), 263-292.

Kamoche, K. (1996). Strategic Human Resource Management within a ResourceCapability View of the Firm. Journal of Management Studies, 33(2), 213-233.

Lambert, S. (2000). Added Benefits: The Link Between Work-Life Benefits and Organizational Citizenship Behavior. Academy of Management Journal, 43(5), 801815.

Lane, M. (1993). The Effect of Employee Benefit Satisfaction on Organizational Consequences. In J. Burton (Ed.), Proceedings of the 1992 Meeting of the Industrial Relations Research Association, 99-104. Madison, WI: Industrial Relations Research Association.

Lopes, L. (1987). Between Hope and Fear: The Psychology of Risk. Advances in Experimental Social Psychology, 20, 255-295.

MacEwen, K., Barling, J., Kelloway, E., \& Higginbottom, S. (1995). Predicting Retirement Anxiety: The Roles of Parental Socialization and Personal Planning. Journal of Social Psychology, 135(2), 203-213.

Miceli, M., \& Lane, M. (1991). Consequences of Satisfaction with Pay Systems: Two Field Studies. Industrial Relations, 39, 62-87.

Neuberger, A. (2005). Pensions, Vol. 10. 367-370

Nussbaum, M. \& Sen, A. (1993). Introduction. In The Quality of Life, eds. Nussbaum, M. \& Sen, A., 1-8, Oxford: Clarendon Press.

Osterman, P. (1995). Work Family Programs and the Employment Relationship. Administrative Science Quarterly, Vol. 40: 685-700. 
Oswald, A. (1997). Happiness and Economic Performance. The Economic Journal, 107, November, 1815-1831.

Pantis, Constantijn W.A. (2004). Annuities and Retirement Well-Being. In Pension Design and Structure: New Lessons From Behavioral Finance, eds. Olivia S. Mitchell and Stephen P. Utkus, 259-274. Oxford: Oxford University Press.

Rand Corporation, (2004). Rand HRS Data File. http://www.rand.org/labor/aging/dataprod/

Rappaport, A. (2004). Retirement Perspective: Exploding the Myth that Employees Always Prefer Defined Contribution Plans. www.mercer.com

Rosenbloom, J.S. (2001). The Handbook of Employee Benefits. New York, NY:McGraw Hill

Sen, A. (1987). On Ethics and Economics. Blackwell.

Sen, A. (1993). Capability and Well-Being. In The Quality of Life, eds. Nussbaum, M. \& Sen, A., 30-53, Oxford: Clarendon Press.

Schieber, J. \& Shoven, J. (1999). The Real Deal: The History and Future of Social Security. New Haven and London, Yale University Press.

Shefrin, H., \& Statman, M. (2000). Behavioral Portfolio Theory. Journal of Financial and Quantitative Analysis, 35, 2, 127-151.

University of Michigan. (2004). Health and Retirement Survey. http://hrsonline.isr.umich.edu/

US Department of Labor. (2004). Employee Participation in Defined Benefit and Defined Contribution Plans, 1985-2000.

http://www.bls.gov/opub/cwc/content/cm20030325tb01.stm

US Department of Labor. (2006). Employee Benefits in Private Industry in the United States, March 2006. P. 6.

http://www.bls.gov/ncs/ebs/sp/ebsm0004.pdf

US Department of Labor. (2008). Employer Costs for Employee Compensation Summary - March 2008.

http://www.bls.gov/news.release/ecec.nr0.htm

Weller, C. \& Wolff, E. (2005). Retirement Income: The Crucial Role of Social Security. Washington, D.C.: Economic Policy Institute. 
Westerman, J., \& Sundali, J. (2005). The Transformation of Employee Pensions in the United States: Through the Looking Glass of Organizational Behavior. Journal of Organizational Behavior, 26(1), 99-103.

Williams, M., Malos, S., \& Palmer, D. (2002). Benefit System and Benefit Level Satisfaction: An Expanded Model of Antecedents and Consequences. Journal of Management, 28(2), 195-215.

Wilson, M, Northcraft, G.B. \& Neale, M.A. (1985). The Perceived Value of Fringe Benefits. Personnel Psychology, 38 (2), 309-320 